\title{
Stable carbon and oxygen isotopes in tree rings show physiological responses of Pericopsis elata to precipitation in the Congo Basin
}

\author{
Daniele Colombaroli*,1, Paolo Cherubini ${ }^{\dagger}$, Maaike De Ridder ${ }^{\ddagger}$, , Matthias Saurer ${ }^{\#}$, Benjamin Toirambe ${ }^{\ddagger}$, \\ Noëmi Zweife** and Hans Beeckman ${ }^{\ddagger}$
}

\author{
* Institute of Plant Sciences and Oeschger Centre for Climate Change Research, University of Bern, Bern, Switzerland \\ $\dagger$ WSL Swiss Federal Institute for Forest, Snow and Landscape Research, Birmensdorf, Switzerland \\ $¥$ Wood Biology Service, Royal Museum for Central Africa, Tervuren, Belgium \\ $\S$ Laboratory for Wood Technology, Ghent University, Ghent, Belgium \\ \# Laboratory of Atmospheric Chemistry, Paul Scherrer Institute, Villigen, Switzerland \\ (Received 7 December 2015; revised 8 March 2016; accepted 9 March 2016; first published online 12 April 2016)
}

\begin{abstract}
In equatorial regions, where tree rings are less distinct or even absent, the response of forests to highfrequency climate variability is poorly understood. We measured stable carbon and oxygen isotopes in anatomically distinct, annual growth rings of four Pericopsis elata trees from a plantation in the Congo Basin, to assess their sensitivity to recorded changes in precipitation over the last $50 \mathrm{y}$. Our results suggest that oxygen isotopes have high common signal strength $(\mathrm{EPS}=0.74)$, and respond to multi-annual precipitation variability at the regional scale, with low $\delta^{18} \mathrm{O}$ values (28-29\%) during wetter conditions (1960-1970). Conversely, $\delta^{13} \mathrm{C}$ are mostly related to growth variation, which in a light-demanding species are driven by competition for light. Differences in $\delta^{13} \mathrm{C}$ values between fast- and slow-growing trees $(c .2 \%)$, result in low common signal strength $(\mathrm{EPS}=0.37)$ and are driven by micro-site conditions rather than by climate. This study highlights the potential for understanding the causes of growth variation in $P$. elata as well as past hydroclimatic changes, in a climatically complex region characterized by a bimodal distribution in precipitation.
\end{abstract}

Key Words: Africa, Congo, stable isotopes, tree rings, tropical rain forest

\section{INTRODUCTION}

The Congo Basin is a key area for the global carbon cycle, hosting the second largest tropical forest after the Amazon (Detwiler \& Hall 1988). Yet, the degree to which the Central African forest will cope with future global changes is under debate (Otto et al. 2013, Zelazowski et al. 2011). Understanding centennial scale growth dynamics of past tropical forests can provide baseline information for assessing future climate change impacts; unfortunately, such data are rare before the instrumental record (Gebrekirstos et al. 2014, Rozendaal \& Zuidema 2011).

Tree rings can potentially fill this gap in our knowledge. In the tropics, the use of tree rings has been hindered by the lack of annual rings in most tree species, thus limiting their application for dendrochronological studies (Loader et al.

\footnotetext{
${ }^{1}$ Corresponding author. Email: daniele.colombaroli@ips.unibe.ch
}

2013, Rozendaal \& Zuidema 2011). However, tree-ring stable carbon and oxygen isotopes $\left(\delta^{13} \mathrm{C}, \delta^{18} \mathrm{O}\right)$ in some cases have been shown to reflect tree growth response to climate forcing, even when annual rings are missing or unclear (Evans \& Schrag 2004, Poussart et al. 2006).

Stable isotopes in tree rings are determined by distinct processes (McCarroll \& Loader 2004). Generally, tree physiology controls $\delta^{13} \mathrm{C}$, with fractionation occurring during uptake of $\mathrm{CO} 2$ through the stomata (diffusion, c. $-4 \%$ ) and during $\mathrm{CO} 2$-fixation (carboxylation, c. $-27 \%$,). $\delta^{13} \mathrm{C}$ is therefore influenced by changes in the relative importance of diffusional versus biochemical limitations of photosynthesis (Francey \& Farquhar 1982). Such changes occur as a result of environmental factors like water availability, light, but also nutrients and competition with neighbouring trees (McCarroll \& Loader 2004). In contrast, tree-ring oxygen isotopes are more directly influenced by physical and climatic factors, rather than tree-internal physiological fractionations. Precipitation amount (amount effect, i.e. the depletion 
of heavy isotopes with increasing rainfall), together with altitudinal and continental effects (i.e. Rayleigh fractionation) are the most relevant factors determining $\delta^{18} \mathrm{O}$ in precipitation (equilibrium processes, Dansgaard 1964). This precipitation isotope signal, taken up by the roots, is the major signal incorporated in plants, although further modification occurs in the plant leaves during transpiration, causing an enrichment controlled mainly by relative humidity and relatively constant biochemical enrichment (Roden et al. 2000). Stable isotope tree-ring series in the tropics are still rare and a relatively recent approach compared with temperate zones (Barbour 2007, Helle \& Schleser 2004, McCarroll \& Loader 2004, Schleser et al. 1999). Additionally, the attribution of isotopic changes to single environmental factors is often difficult to achieve (Gebrekirstos et al. 2014). This is particularly true for regions characterized by a bimodal distribution in precipitation (e.g. Eastern Congo), where the responses of species are controlled by multiple factors and still poorly documented.

In this study, we explore the nature of isotopic variability in tree-ring series from Pericopsis elata (Harms) van Meeuwen, a light-demanding species common in moist semi-deciduous forest of Central and Western Africa (Vivien \& Faure 2011), and with the advantage of annual growth rings (De Ridder et al. 2014). Specifically, we combine stable isotopes, ring-widths and precipitation data to test whether stable isotopes may record climate variability over the last $c .50 \mathrm{y}$, in an area characterized by a bimodal distribution in precipitation (two wet and two dry seasons). Alternatively, the isotopic composition in Pericopsis elata may be mostly driven by local growth conditions (e.g. light availability), thus masking the climate signal. For this study, we focused on two slowand two fast-growing trees, to account for the relative importance of tree growth for isotopic fractionation.

\section{METHODS}

\section{Site}

The Yoko reserve $\left(00^{\circ} 21^{\prime}-00^{\circ} 06^{\prime} \mathrm{N}, 025^{\circ} 13^{\prime}-025^{\circ} 17^{\prime} \mathrm{E}\right)$ is a protected area (Institut Congolais de la Conservation de la Nature, ICCN) located c. $20 \mathrm{~km}$ south of Kisangani (Tshopo district, Province Orientale, Democratic Republic of Congo, Figure 1). The area is relatively flat and with a total area of approximately 7000 ha, delimited by the Congo and the Biaro rivers (Figure 1b). It is presently covered by dense and semideciduous forest stands (Congolese mixed moist semievergreen forest), including light-demanding ( $P$. elata, Milicia excelsa, Musanga cecropioides, Piptadeniastrum africanum) and shade-tolerant tree species (Cynometra sp., Gilbertiodendron dewevrei, and mostly Scorodophloeus zenkeri, see Lomba-Bosombo 2002). Mean temperature in the region is around $25^{\circ} \mathrm{C}$ with maximum insolation between January-February and a minimum in August (Kisangani meteorological station, 1901-2009). Monthly precipitation (annual mean $1700 \mathrm{~mm}$ ) shows a bimodal pattern (short and long rainy seasons: April-May and September-November, respectively), associated with the latitudinal migration of the Intertropical Convergence Zone (ITCZ). Relative humidity in the Congo Basin is mainly delivered by westerly winds from the Gulf of Guinea and recycled through the rain forests, before being delivered further east (Williams et al. 2012). Continentalscale climate patterns, such as the ENSO or the Indian Ocean Dipole (IOD) can also affect precipitation variability over decades (Farnsworth et al. 2011).

Trees of Pericopsis elata have been planted in 1953 and 1954 in the reserve $\left(00^{\circ} 19^{\prime} 35.2^{\prime \prime} \mathrm{N}, 25^{\circ} 15^{\prime} 29.7^{\prime \prime} \mathrm{E}\right)$, with a distance between trees of $c .5 \mathrm{~m}$. A few Terminalia superba Engl. \& Diels trees were planted close to the Pericopsis elata, and some other species (such as Elaeis guineensis Jacq. palms, Piptadeniastrum africanum (Hook.f.) Brenan and Petersianthus macrocarpus (P. Beauv.) Liben) established spontaneously between the planted trees. In 2010, the distance between trees was $c .9 \mathrm{~m}$. Although a more complete description of the forest stands and micro-site conditions were not available in this remote area at the time of sampling, edaphic conditions were relatively homogeneous in the plantation, and competition for light is the main determinant of tree growth in this light-demanding species. For our study, we randomly selected from the plantation trees with regular stems and without scars.

\section{Ecology of Pericopsis elata}

Among the long-living, light-demanding tree species, $P$. elata is an ecologically versatile species, coping with both dry and waterlogged conditions (Bourland et al. 2012). It can be found in small (1 ha) aggregates, reproducing with anemochoric dispersal. Because of decades of exploitation for its highly valuable timber, it is included in the CITES list of protected species. To establish, Pericopsis elata requires forest-gap disturbances (Hawthorne 1995); its distribution in Central Africa was favoured by moderate human impact before the colonial period (Brncic et al. 2007). Generally its growing season is determined by seasonal precipitation distributions (from March-April to November, Appendix 1), and wood formation is only interrupted for a few months during the driest season (December-March).

\section{Tree-ring widths and stable isotopes $\left(\delta^{13} \mathrm{C}, \delta^{18} 0\right)$ analysis}

We collected stem discs from two slow- (discs 1 and 2) and two fast-growing trees (discs 3 and 4, Figure 2a), 
(a)

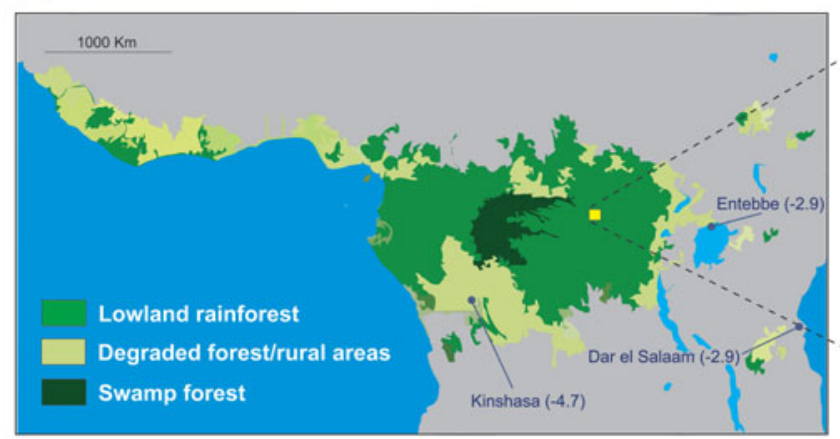

(b)

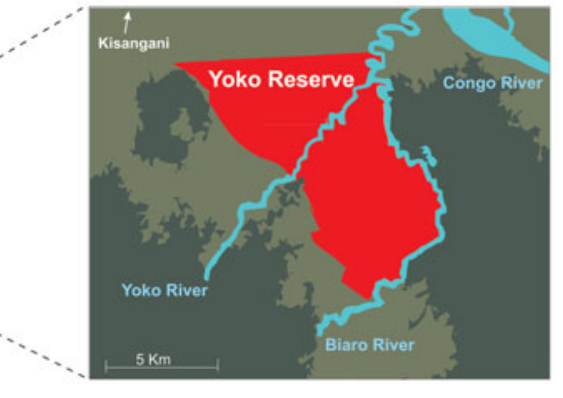

\section{(c)}

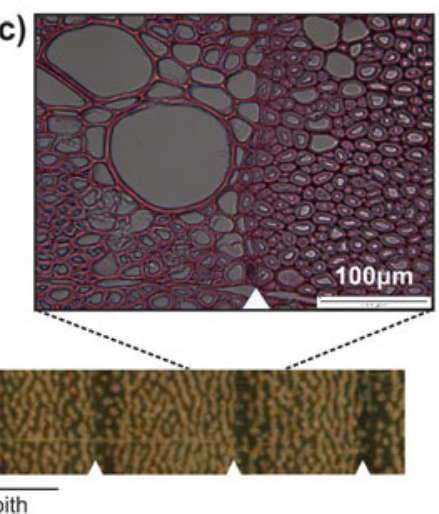

(d)

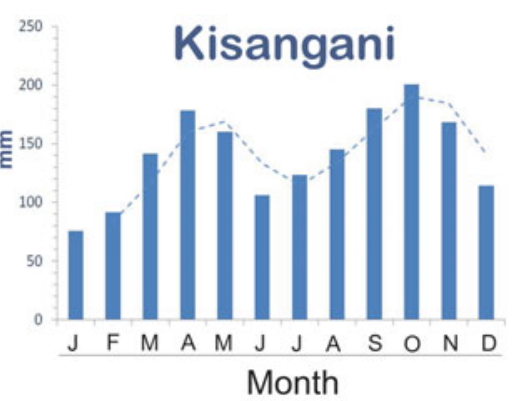

(e)

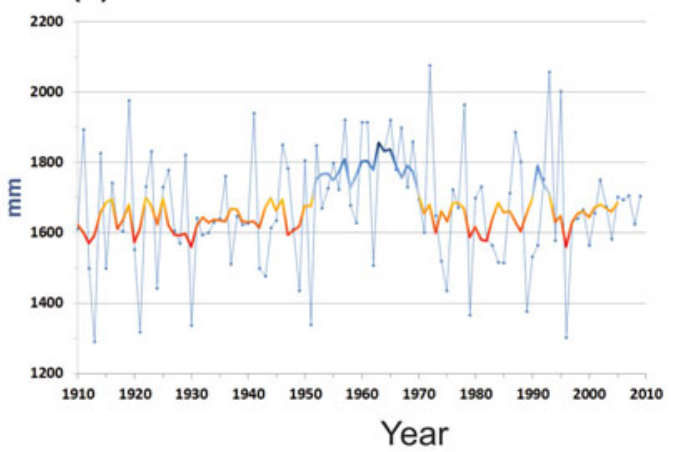

Figure 1. Map of the study site, with MODIS derived distribution of central African rain forest (a) (modified after Mayaux et al. 2013); values in brackets indicate long-term average $\delta^{18} \mathrm{O}$, weighted by amount of precipitation at selected GNIP stations (Rozanski et al. 1996). The location of the Yoko reserve (b) (modified after Lomba-Bosombo 2002). The microscopic view of a Pericopsis elata tree ring (c), showing the anatomically distinct ring border, separating early (dark fibres) and late seasons (light fibres with parenchyma) (c). Monthly rainfall changes, showing the bimodal distribution of precipitation (d). Changes in total precipitation near Kisangani over the last century (van Oldenborgh \& Burgers 2005); the thick line represents the 5-y moving average (e).

in the Yoko reserve during 2009-2010. Discs were cut at approximately $30 \mathrm{~cm}$ above soil level and treering widths were measured on four rays for each disc, following standard procedures (De Ridder et al. 2013a). We measured each ring considering the wood anatomical patterns specific to P. elata: a dark layer of fibres and no vessels, followed by a lighter layer with parenchyma produced later in the season (Figure 1c). An anatomically distinct growth-ring border is visible, and is also supported by information from cambial wounding experiments. For each disc, we used one measured ray (i.e. with no missing years, where possible), instead of the average tree-ring series. Cross-dating between trees (Douglas 1941) was not successful due to different growth history of trees (Figure 2a).

We measured stable isotopes $\left(\delta^{18} \mathrm{O}, \delta^{13} \mathrm{C}\right)$ on each tree and ring separately, without pooling samples for maximizing sample size (as sometimes done for temperate species, Saurer et al. 1995). This implied a lower number of measured samples, but allowed accounting for differences in the isotopic signal due to varying growth patterns (Figure 2a). For isotope analysis, we manually split each selected ray with a scalpel obtaining $c .50$ samples per disc, with each sample representing $1 \mathrm{y}$ of tree growth. Alpha cellulose was extracted using standard methods from $1 \mathrm{mg}$ of ground wood material prior to stable isotope analysis (Boettger et al. 2007). We excluded the innermost rings because photosynthesis rates may be different in the first years of growth and the influence of soil-respired $\mathrm{CO} 2$ higher (Fichtler et al. 2010). In total, we considered 47 rings for disc 1 (1962-2008), 51 for disc 2 (1960-2010), 53 for disc 3 (1958-2010) and 51 for disc 4 (1960-2010, Table 1). For data analyses, we considered the common period between discs (1962-2008).

To determine carbon isotopic ratios, samples were combusted to carbon dioxide at $1025^{\circ} \mathrm{C}$ using an elemental analyser (EA-1110; Carlo Erba Thermoquest, Milan, Italy), and the isotope ratios measured with a Delta $\mathrm{S}$ isotope ratio mass spectrometer (Thermo Finnigan, Bremen, Germany). Oxygen isotopic ratios were determined after pyrolysis to $\mathrm{CO}$ at $1420^{\circ} \mathrm{C}$ using a Pyro cube (Elementar, Hanau, Germany) connected in continuous flow mode to a Delta Plus XP (Thermo Finnigan, Bremen, Germany). 
Table 1. Pericopsis elata tree-ring series used in this study. Trees were sampled in 2008 and 2010 in an even-aged plantation (1953-1954) located in the Yoko reserve (Eastern Congo). Age interval considered for stable isotope series did not include the first years of growth. Discs 2-4 were harvested at the beginning of the growing season, resulting in a not fully formed ring in year 2010.

\begin{tabular}{|c|c|c|c|c|c|c|c|}
\hline Disc & $\begin{array}{l}\text { Museum } \\
\text { code }\end{array}$ & $\begin{array}{c}\text { Year of } \\
\text { plantation }\end{array}$ & Gbh $(\mathrm{cm})$ & $\begin{array}{l}\text { Tree height } \\
\text { (m) }\end{array}$ & Sampling date & $\begin{array}{c}\text { Age interval } \\
\text { considered for } \\
\delta^{18} \mathrm{O} \text { and } \delta^{13} \mathrm{C} \\
\text { analyses }\end{array}$ & $\begin{array}{l}\text { No. of rings } \\
\text { analysed }\end{array}$ \\
\hline 1 & Tw60900a & 1954 & 97 & $20-22$ & 11 August 2008 & $1962-2008$ & 47 \\
\hline 2 & Tw622010a & 1954 & 125.9 & NA & 24 Мау 2010 & $1960-2010$ & 51 \\
\hline 3 & Tw62209a & 1953 & 150.6 & $25-28$ & 25 May 2010 & $1958-2010$ & 53 \\
\hline 4 & Tw62212a & 1953 & 178.8 & NA & 24 May 2010 & $1960-2010$ & 51 \\
\hline
\end{tabular}

( a ) $\simeq \operatorname{Disc} 1$ (Tw60900a) $\quad \longrightarrow$ Disc 2 (Tw 62210a)
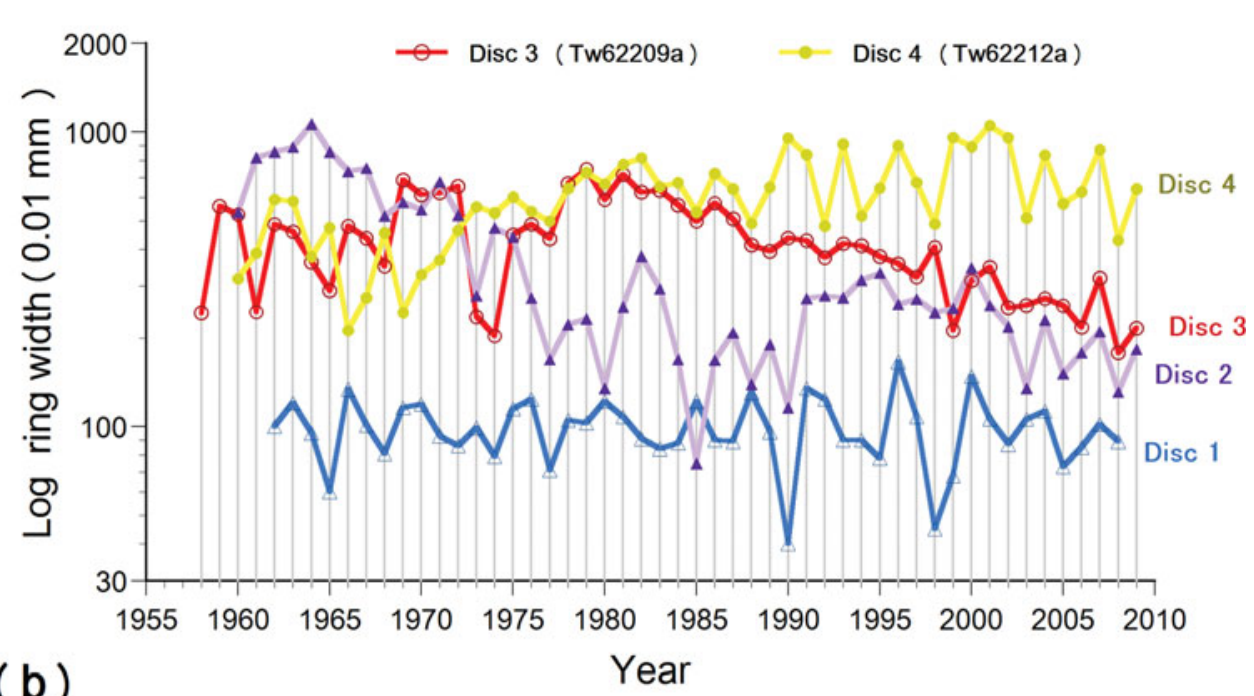

(b)

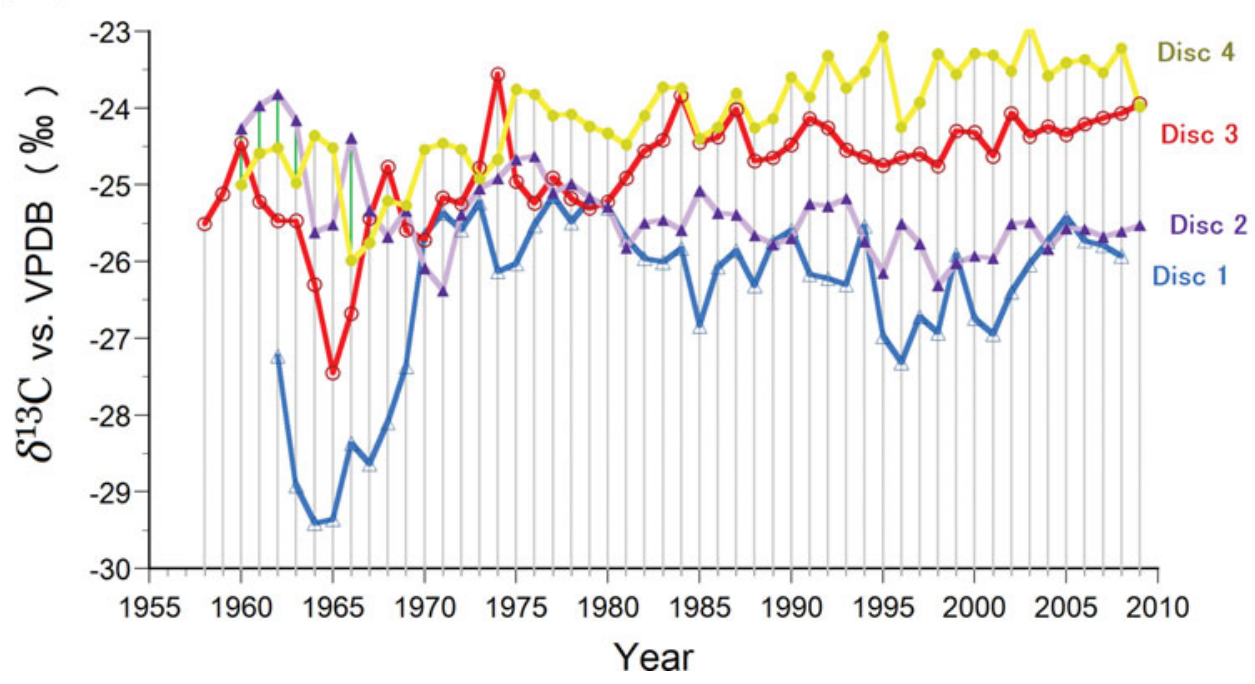

Figure 2. Pericopsis elata tree-ring widths showing slow- (discs 1 and 2) and fast-growing trees (discs 3 and 4); values are on a log scale to highlight variation in low $\delta^{13} \mathrm{C}$ (a). $\delta^{13} \mathrm{C}$ series on alpha-cellulose expressed relative to the Vienna Pee Dee belemnite VPDB; $\delta^{13} \mathrm{C}$ values were corrected by adding the difference between preindustrial and present $\delta^{13} \mathrm{C}$, to account for the increase in carbon dioxide from fossil fuels since 1950 (b). 
Carbon $\left(\delta^{13} \mathrm{C}\right)$ and oxygen $\left(\delta^{18} \mathrm{O}\right)$ isotopic ratios are expressed relative to the Vienna Pee Dee belemnite VPDB $\left(\delta^{13} \mathrm{C}\right.$, Coplen 1995), and Vienna Standard Mean Ocean Water VSMOW $\left(\delta^{18} \mathrm{O}\right)$, respectively (details in Saurer \& Siegwolf 2004). The overall precision was $0.1 \%$ for carbon and $0.2 \%$ for oxygen. For $\delta^{13} \mathrm{C}$, we accounted for the global increase in carbon dioxide from fossil fuels since 1950 (Epstein et al. 1990), which reduced the ${ }^{13} \mathrm{C}$ content in the atmosphere (McCarroll et al. 2010). We therefore corrected all $\delta^{13} \mathrm{C}$ values by adding the difference between pre-industrial and present $\delta^{13} \mathrm{C}$, for each year.

\section{Data analysis}

Instrumental climate data in the tropics are generally sparse and discontinuous; we therefore compared different precipitation datasets from instrumental records, including areas close to the sampling site (Kisangani, $20 \mathrm{~km}$ distant), or in the region (Yangambi, $100 \mathrm{~km}$ distant). Since most of these data are too fragmentary, or do not entirely cover our series (1958-2009), we only considered the interpolated (between 0 and $1^{\circ} \mathrm{N}$ and $24^{\circ}$ and $25^{\circ} \mathrm{E}$ ) precipitation time-series from 1908 to 2009, at local-to-regional scale (Royal Netherlands Metereological Institute KNMI, van Oldenborgh \& Burgers 2005, and NCAS British Atmospheric Data Centre). Temperature has generally little influence on growth conditions of tropical species, at least in this area (De Ridder et al. 2013b), and indeed our stable isotope series are only weakly correlated with temperature (Appendix 1). The KNMI data show a period of higher annual precipitation in the 1960s, followed by a drying trend (Figure 1e). When decomposing the time series, the distribution of seasonal precipitation during the two halves of the rainy season (short and long wet seasons) is also variable over the decadal time-scale (Appendix 1). We therefore compared our isotopic data, with changes in monthly and seasonal precipitation over the last $50 \mathrm{y}$ (Appendices 2 and 3). All time-series are presented with raw data (with exception for the $\delta^{13} \mathrm{C}$ corrected for fossilfuel emissions). No standardization was applied to avoid losing any low-frequency signal (Robertson et al. 1997).

For carbon and oxygen isotopes, we calculated the expressed population signal EPS (Briffa \& Jones 1990) to assess the common signal strength of different trees. We used the averaged oxygen isotopes values (but not $\delta^{13} \mathrm{C}$ series, because of lower inter-series correlations), to check whether oxygen isotopes in our series are related to precipitation data. The averaged $\delta^{18} \mathrm{O}$ values are reported with confidence intervals calculated with a Student's- $t$ distribution. Additionally, we calculated the coefficient of variation CV (a normalized measure of dispersion), RBAR (a measure of common variance) and standard deviation statistics (Frank et al. 2007, Kress et al. 2010).
We also considered GNIP stations (Global Network of Isotopes in Precipitation) located in the west and the east of the Congo Basin (Figure 1a), to assess the isotopic signature of different source of air masses on precipitation (Araguas-Araguas et al. 2000). We only used the weighted mean as reported in Rozanski et al. (1996), because GNIP series are often discontinuous and do not allow a full comparison with our $\delta^{18} \mathrm{O}$ series. Also, the closest station with continuous data (Entebbe, Uganda, Figure 1a), shows an isotopic signature which is mostly biased by moisture derived from evaporated water from Lake Victoria (Rozanski et al. 1996), and therefore not considered in this study.

\section{RESULTS}

\section{Ring-width series and stable isotopes}

The analysed stem discs showed large differences in ring-width patterns (Figure 2a), reflecting the different growth dynamic of trees growing in monospecific plantations. Disc 1 showed relatively constant narrow rings, suggesting less favourable conditions for tree growth, likely caused by the presence of a nearby growing Terminalia superba tree. Disc 1 also showed series of narrower rings, with minimum values in 1965, 1990 and 1998 (Figure 2a). Discs 2 and 3 exhibited highly variable ring-widths, with narrower rings after 1971 (disc 2) and 1980 (disc 3, Figure 2a). Disc 4 was still dominant at the time of sampling, and under more open conditions and light availability; ring widths showed a constant growth pattern, with favourable conditions for tree growth after 1977 (Figure 2a).

The common signal strength was different between $\delta^{13} \mathrm{C}$ and $\delta^{18} \mathrm{O}$ series, with Expressed Population Signal (EPS) much lower for $\delta^{13} \mathrm{C}(=0.37)$ than for $\delta^{18} \mathrm{O}(=$ 0.74 ). Fast-growing trees (discs 3 and 4 ) were less depleted (i.e. higher $\delta^{13} \mathrm{C}$ values) than slow-growing trees (i.e. disc 1, Figure 2b). For instance, between 1975 and 2010, discs 3 and 4 showed $2 \%$ higher values on average than discs 1 and 2 (c. $-24 \%$ vs $-26 \%$, Figure 2 b). Disc 2, with high variability in tree-ring widths, had lower $\delta^{13} \mathrm{C}$ values when tree growth decreased (after 1971, Figure 2). We also observed more variability in $\delta^{13} \mathrm{C}$ during the period with highest total precipitation (1958-1970, Figure 1e), with disc 1 (slow-growing tree) reaching values as low as $-29 \%$.

Correlations between oxygen and carbon, and between ring widths and stable isotopes, were significant only in a few discs and depended on their growth rates (Table 2). For instance, $\delta^{18} \mathrm{O}$ and $\delta^{13} \mathrm{C}$ were significantly correlated $(\mathrm{r}=0.53, \mathrm{P}<0.01)$ only in disc 1, i.e. the tree with the slowest growth rates. Ring-widths and $\delta^{13} \mathrm{C}$ were significantly correlated only in disc $4(\mathrm{r}=0.54, \mathrm{P}<0.01)$, 
Table 2. Pearson's product-moment correlation between ring widths and stable isotopes in Pericopsis elata, measured on four discs from the Yoko reserve (Eastern Congo). Positive correlations exist between $\delta^{18} \mathrm{O}$ and $\delta^{13} \mathrm{C}$ in disc 1 and between $\delta^{13} \mathrm{C}$ and tree growth in disc 4; asterisk $\left({ }^{*}\right)$ indicates significance level at $\mathrm{P}<0.01$. Correlations are calculated over the common interval 1962-2008.

\begin{tabular}{lcccc}
\hline Disc & $\begin{array}{c}\text { Growth } \\
\text { rate }\end{array}$ & $\begin{array}{c}\delta^{18} \mathrm{O} v s \\
\delta^{13} \mathrm{C}\end{array}$ & $\begin{array}{c}\delta^{13} \mathrm{C} v s \\
\text { avgGrowth }\end{array}$ & $\begin{array}{c}\delta^{18} \mathrm{O} v s \\
\text { avgGrowth }\end{array}$ \\
\hline 1 & Slow & $0.53^{*}$ & -0.10 & -0.12 \\
2 & Slow & -0.25 & 0.30 & -0.58 \\
3 & Fast & 0.29 & -0.30 & -0.05 \\
4 & Fast & 0.31 & $0.54^{*}$ & 0.28 \\
\hline
\end{tabular}

a fast-growing tree (Figure 2a). $\delta^{18} \mathrm{O}$ and ring widths were instead weakly correlated for all discs (Table 2).

\section{$\delta^{18} \mathrm{O}$ and precipitation data $1958-2009$}

Considering the high common signal strength for $\delta^{18} \mathrm{O}$, we averaged $\delta^{18} \mathrm{O}$ series (Figure 3a) to allow comparison with the available $50 \mathrm{y}$ of instrumentally recorded changes in precipitation (Appendix 1). At multi-annual scale, trends in $\delta^{18} \mathrm{O}$ followed changes in total precipitation (but not in temperature, Appendix 1). In general, low $\delta^{18} \mathrm{O}$ values occurred during 1960-1970, i.e. the period with higher precipitation (and to a lesser extent, during 1990-1995, Figure 3b-d). This period was followed by increasing $\delta^{18} \mathrm{O}$ values and a declining precipitation trend (i.e. after 1970, Figure 3d). We found, however, low correlations between $\delta^{18} \mathrm{O}$ series and annual or seasonal precipitation (Appendix 2 and 3). In particular, the weakened $\delta^{18} \mathrm{O}$ signal strength after 1980 (see increased C.I. in Figure 3b), was due to changing growth rates in disc 2, particularly after 1988 (Figure 2a), overall weakening the correlation between total precipitation and our $\delta^{18} \mathrm{O}$ series. Low signal strength in $\delta^{18} \mathrm{O}$ was also particularly marked for years 1965, 1984 and 1992-1994 (high STDEV and CVar in Figure 3c), and reflected by lower mean inter-series correlation (e.g. low RBAR between 1992-1995). By considering 5-y average values, the correlation between total precipitation and $\delta^{18} \mathrm{O}$ series (all discs) was significant $(\mathrm{r}=-0.7, \mathrm{P}<0.01)$.

\section{DISCUSSION}

\section{Physiological and climatic controls over tree-ring $\delta^{13} \mathrm{C}$}

The $\delta^{13} \mathrm{C}$ signal in tree-rings is usually interpreted as the interplay between stomatal conductance (influenced by atmospheric humidity and soil moisture) and photosynthesis (influenced by light and nutrients availability), determining the total amount of intracellular $\mathrm{CO}_{2}$ in the leaf, and therefore the carbon isotope discrimination (McCarroll \& Pawellek 2001). For instance, high $\delta^{13} \mathrm{C}$ values may result from increased photosynthesis or stomatal closure, depending on the relative importance of moisture for tree growth in the considered region. In Kenya, Gebrekirstos et al. (2009) found that moisture stress results in high $\delta^{13} \mathrm{C}$ in different Acacia species from semi-arid areas of East Africa. The (inverse) relationship between precipitation and $\delta^{13} \mathrm{C}$ in tree rings has also been used for regional-scale river flow reconstructions (Wils et al. 2010). In the Congo Basin instead, where moisture stress is a less limiting factor, we expect stomatal conductance to play a minor role for $\delta^{13} \mathrm{C}$ fractionation, compared with photosynthesis. We tested this by comparing our $\delta^{13} \mathrm{C}$ series with precipitation data and ring-width measurements, which can be used as indicators of photosynthetic rates (Worbes et al. 2003).

Our data show a marked inter-tree variability in absolute $\delta^{13} \mathrm{C}$ values (Figure 2). Fast-growing trees tend to have around $2 \%$ higher values on average than slow-growing trees. Such differences in absolute $\delta^{13} \mathrm{C}$ have also been observed for subtropical forest species growing under different growth conditions, with lower $\delta^{13} \mathrm{C}$ values in shade conditions (West et al. 2001). Indeed, shading is a limiting factor for tree growth, especially for long-lived, light-demanding species such as P. elata (Bourland et al. 2013). Instead, water stress is not controlling growth variation between trees, as stomatal closure would result in higher $\delta^{13} \mathrm{C}$, rather than low $\delta^{13} \mathrm{C}$ values as in our data (i.e. in the slowgrowing discs 1 and 2, Figure 2). In agreement with the carbon fractionation theory (McCarroll \& Pawellek 2001) our data therefore suggest that variation in ${ }^{13} \mathrm{C}$ is driven by individual growth histories of each tree, which at our site is mainly determined by variation in light availability. For instance, Disc 1 grew under reduced light conditions, due to a nearby Terminalia superba tree. The weak correlation between $\delta^{13} \mathrm{C}$ and ring widths on the yearly basis (Table 2) is possibly due to the relative importance of photosynthesis and stomatal conductance, which may be different during wet (e.g. 1950-1970) and dry periods (e.g. after 1970, Figure 3d), thus indicating an unstable climate-isotope relationship (Reynolds-Henne et al. 2007). In our data, photosynthetic rates are reflected in the $\delta^{13} \mathrm{C}$ variability in one tree only (disc 4 , fast-growing), as suggested by the correlation with ring widths $(\mathrm{r}=0.54$, $\mathrm{P}<0.01$ ).

In the slow-growing disc $1, \delta^{13} \mathrm{C}$ variability is instead more controlled by precipitation, as shown by $\delta^{13} \mathrm{C}$ values before 1970 (as low as $-29 \%$, Figure $2 b$ ). Indeed, low $\delta^{13} \mathrm{C}$ values in slow-growing trees may result from the additive effect of low light availability (low photosynthetic rate), and wetter conditions (high stomatal conductance). A further mechanism explaining such low $\delta^{13} \mathrm{C}$ values could be related to $\mathrm{CO}_{2}$ from soil respiration (containing 
(a)

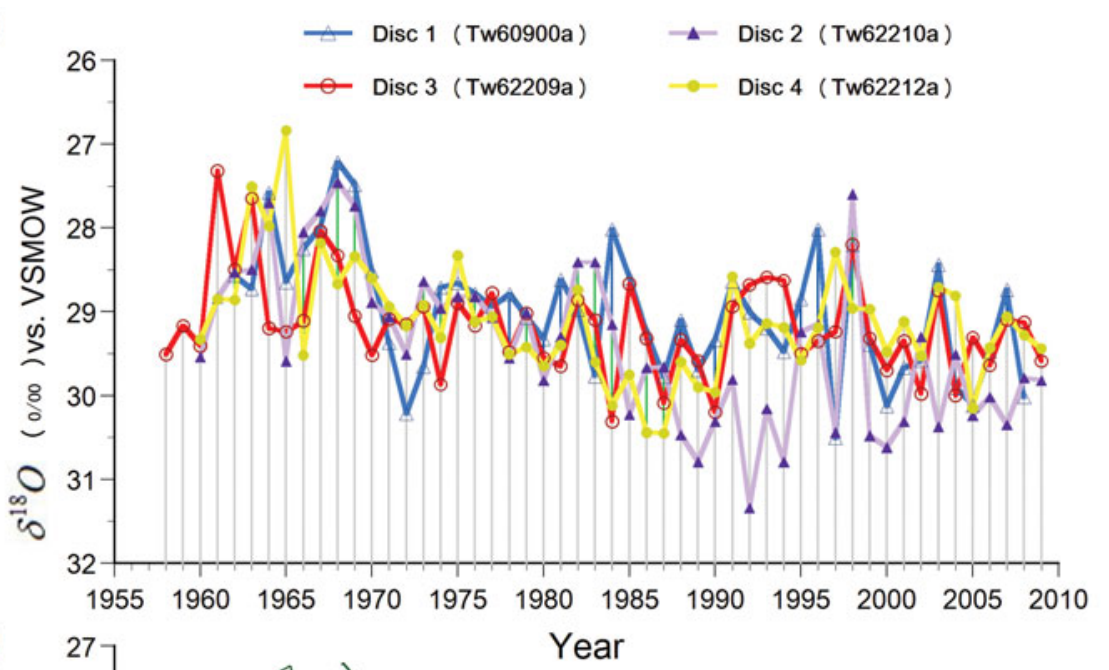

(b)

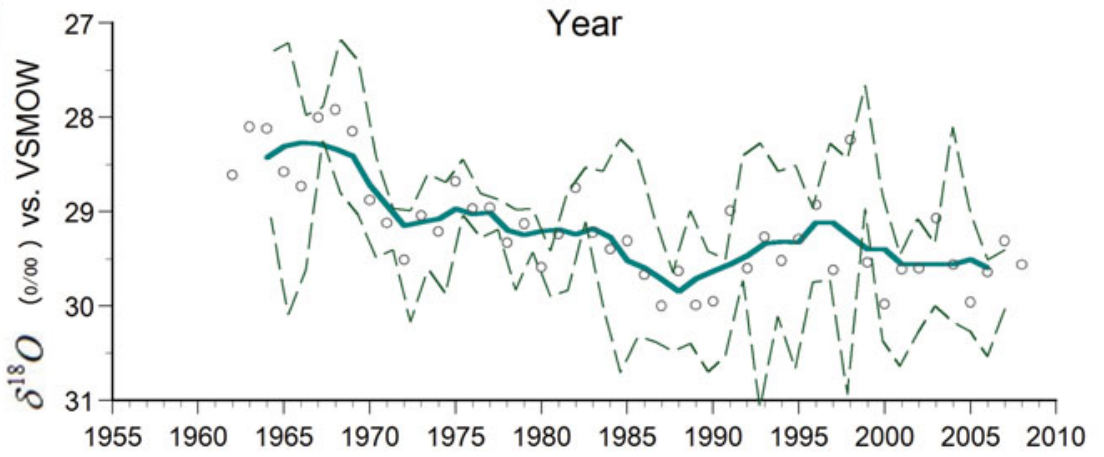

(c)

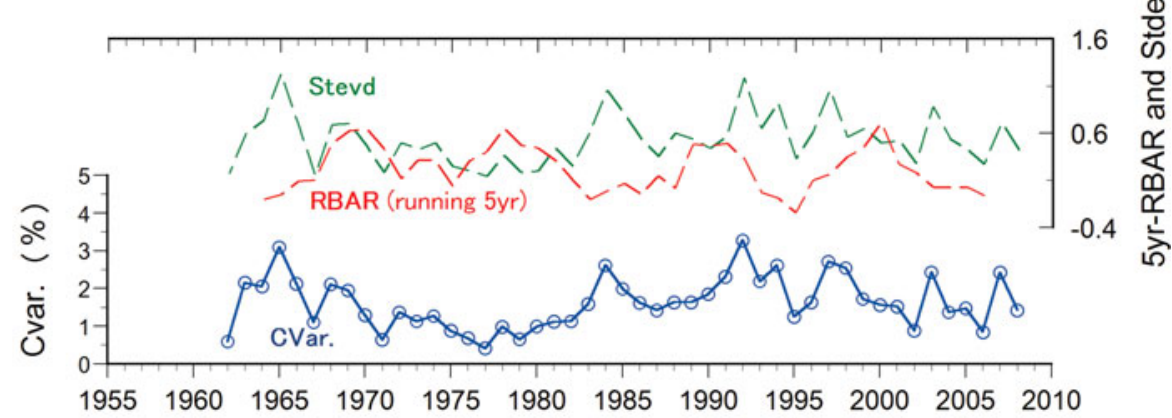

(d)

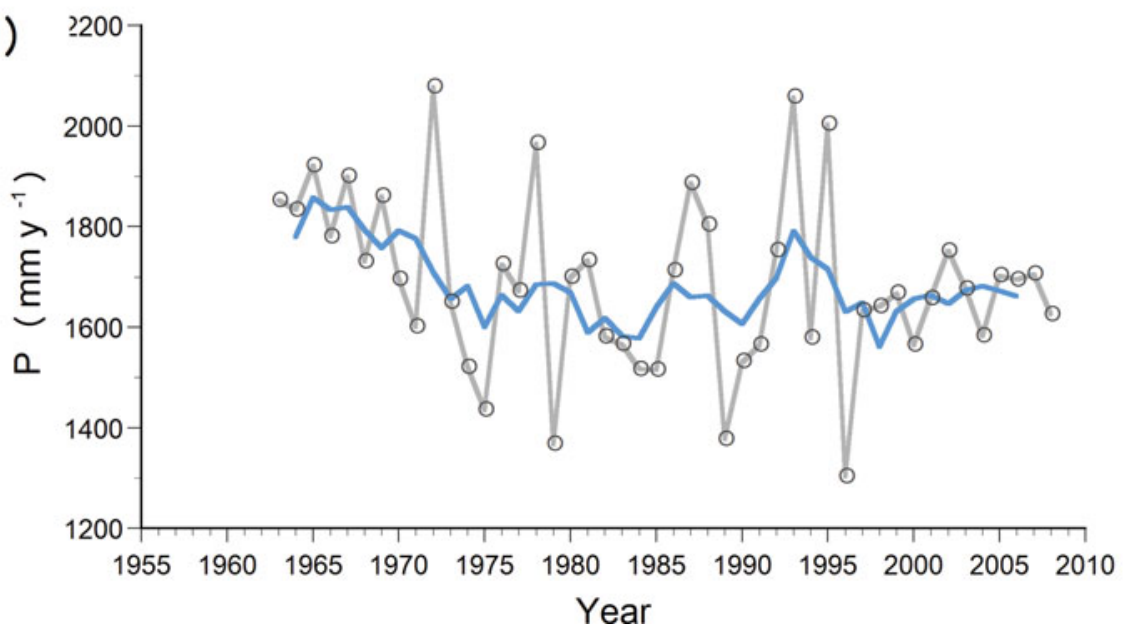

Figure 3. $\delta^{18} \mathrm{O}$ measured on four stem discs from Pericopis elata, relative to the Vienna Standard Mean Ocean Water VSMOW. Raw $\delta^{18} \mathrm{O}$ series on alpha-cellulose (a); note the inverted $\mathrm{Y}$ axis to allow comparison with precipitation variability. Averaged $\delta^{18} \mathrm{O}$ series (b); solid line represents the 5-y running mean and dashed lines the $90 \%$ CI of the four averaged series. Standard deviation (SD), 5-y running mean correlation coefficient (RBAR) and coefficient of variation (CV) (c). Total precipitation variability over the last $50 \mathrm{y}$; the blue line represents the 5-y running average (d). 
less ${ }^{13} \mathrm{C}$ ), during early stages of growth in a more closed canopy (isotope juvenile effect, Fichtler et al. 2010). Earlystage effects are instead less marked (or absent) in the other trees.

Taken together, such variable responses of carbon fractionation to photosynthesis and stomatal conductance in trees of different growth histories may explain why overall $\delta^{13} \mathrm{C}$, tree-ring width and precipitation series are weakly related in our series (Appendix 2 and 3). Indeed, multiple controls over $\delta^{13} \mathrm{C}$ fractionation such as nutrient availability (Kyereh et al. 1999, Veenendaal et al. 1996), root development (Ampofo 1972), solar irradiance and forest openness (e.g. grazing, fire, logging), are difficult to disentangle at this step. Notwithstanding these uncertainties, our data suggest that variation in $\delta^{13} \mathrm{C}$ in Pericopsis elata is driven by light availability, rather than water stress.

\section{Relationship between tree-ring $\delta^{18} 0$ and precipitation}

Factors controlling $\delta^{18} \mathrm{O}$ in tree rings mostly depend on precipitation sources and physiological processes, including transpiration (McCarroll \& Loader 2004). Rayleigh fractionation should result in ${ }^{18} \mathrm{O}$ depletion (i.e. low $\delta^{18} \mathrm{O}$ ) in precipitation at our site, relative to values recorded closer to the ocean source (c. $-2 \%$ to $-3 \%$, Figure 1a; Araguas-Araguas et al. 2000). The isotope ratio of precipitation is also influenced by transpiration processes resulting in recirculation of moisture, a mechanism less subject to ${ }^{18} \mathrm{O}$ depletion than landevaporated water (Gat \& Matsui 1991). Transpiration processes are still relatively less well documented in the Congo Basin than for the Amazon (Gat \& Matsui 1991). This isotopic signature (i.e. high $\delta^{18} \mathrm{O}$ values) is also visible in GNIP stations outside of the Congo basin (Levin et al. 2009), highlighting the relative importance of the Congo rain forest as a source of moisture for neighbouring regions.

Superimposed on these large-scale, spatial patterns are temporal changes in $\delta^{18} \mathrm{O}$ of source precipitation (Levin et al. 2009). These changes should be reflected in the variation of tree-ring oxygen isotopes, assuming source water to be the dominant factor (Saurer et al. 1997), albeit modified by leaf water enrichment and biochemical fractionations (Roden et al. 2000). In our data, the forcing by regional variation in moisture balance is reflected by the strong signal coherency in $\delta^{18} \mathrm{O}$ of tree rings. This value (EPS $=0.74$ ) is slightly lower than that conventionally accepted for reaching the theoretical population chronology $(0.85$, Wigley et al. 1984), but still suggests a common signal in $\delta^{18} \mathrm{O}$ (in contrast to $\delta^{13} \mathrm{C}$ ). In general, the similarity between total precipitation and $\delta^{18} \mathrm{O}$ trends (Figure $3 \mathrm{~b}-\mathrm{d}$ ) shows that regional precipitation has influence over $\delta^{18} \mathrm{O}$, at least at the decadal scale. This anti-phase (i.e. low $\delta^{18} \mathrm{O}$ values with high precipitation) is also more marked during periods of wetter conditions, such as 19501970 (Figure 1e). The Congo Basin and neighbouring areas (Sahel, Horn of Africa) experienced anomalously wetter conditions between 1950 and 1970, a trend out of phase with higher subtropical latitudes (Nicholson 2000), also visible in the westernmost part of the Congo Basin (Samba \& Nganga 2012). It was followed by a reduction in precipitation during the 1970s and 1980s (mostly June-September precipitation, Williams et al. 2012). These decadal scale changes in precipitation are well reflected by our $\delta^{18} \mathrm{O}$ series (Figure $3 \mathrm{~b}-\mathrm{d}$ ). This decreasing trend in precipitation has been attributed to warming of the South Atlantic and Indian Oceans (Hagos \& Cook 2008, Williams et al. 2012), although the relative sea surface temperature forcing (ENSO oscillations) on decadal scale precipitation variability is still relatively unclear (Camberlin et al. 2009, Nicholson 2000).

The observed relationship between $\delta^{18} \mathrm{O}$ and total precipitation recorded in the instrumental record is in agreement with the theoretical fractionation mechanism related to precipitation intensity, or amount effect, and with the leaf isotope enrichment theory (Roden et al. 2000), suggesting higher enrichment under dry conditions (or less enrichment under humid conditions). Such local effects of changes in relative humidity can also be related to atmospheric circulation changes, and are therefore not easy to separate.

In general, the decadal changes in precipitation are mirrored by trends in $\delta^{18} \mathrm{O}$, but the relationship between precipitation and $\delta^{18} \mathrm{O}$ is much weaker on the annual basis (Appendix 2 and 3). Partly, this could be related to the quality of the meteorological data, or data not being fully representative for the study site. In their record from the Amazon, Brienen et al. (2012) explained low $\delta^{18} \mathrm{O}$ precipitation correlation scores with additional depletion resulting from air mass movement over the continent (Rayleigh distillation). If precipitation variability exerts a major control over $\delta^{18} \mathrm{O}$ fractionations over decades, other factors, such as local conditions for tree growth (e.g. disc 2 in Figure 2a), soil water evaporation and leaf water enrichment (Roden et al. 2000), can be dominant at the annual scale, weakening the correlation between precipitation and $\delta^{18} \mathrm{O}$.

\section{Potential and limitations of stable isotope analyses in Pericopsis elata tree rings}

Factors controlling variation in tree-ring isotope ratios at low altitudes in the tropics are still poorly understood, and few tree-ring stable isotope series exist for tropical Africa, due to site remoteness and challenges in treering dating. In this respect, our study contributes 
to ongoing research in the tropics, by focusing on a widespread light-demanding species, and on a key region for palaeoclimatological studies (Russell \& Johnson 2005, Verschuren et al. 2009). Species-specific responses to high-frequency climate variability can also complement information about long-term responses of plant communities in tropical Africa (Brncic et al. 2007, Colombaroli et al. 2014, Oslisly et al. 2013).

Our tree-ring $\delta^{13} \mathrm{C}$ and $\delta^{18} \mathrm{O}$ series generally agree with expected mechanisms for isotope fractionation (McCarroll \& Loader 2004), but with some important differences. First, our results highlight the different sensitivity of stable carbon and oxygen isotopes to climatic factors in the light-demanding $P$. elata. $\delta^{13} \mathrm{C}$ absolute values seem to reflect local differences in growth factors, which in lightdemanding species are controlled by competition for light (and to a lesser extent, by water stress). $\delta^{18} \mathrm{O}$ trends are instead controlled by precipitation over the multi-annual scale (Figure 3), with enriched $\delta^{18} \mathrm{O}$ values reflecting both large-scale atmospheric circulation changes, and humidity-driven enrichment by the leaves of the specific species. Secondly, the use of four trees for stable isotope studies in tree rings is often justified to represent a site isotope signal (Leavitt \& Long 1984). However, this seems not to be sufficient for carbon isotopes series in $P$. elata, given the rather variable response of individual trees (Figure 2a). A larger sample size may be used to strengthen the link between $\delta^{13} \mathrm{C}$ and specific growth patterns (Figure 2), allowing estimation of local growth rates in $P$. elata and, indirectly, its productivity over time (Mbow et al. 2013), or for reconstructing patch-scale dynamics (Gebrekirstos et al. 2014). Also, once applied to a pool of species with different traits (e.g. pioneer vs shade-tolerant), $\delta^{13} \mathrm{C}$ series may allow differentiating the degree of shade tolerance, and thus classify functional types of species with poorly understood ecology (Werner \& Maguas 2010). Oxygen isotopes instead show a stronger signal coherency than carbon in our trees (Figure 3). A higher EPS for $\delta^{18} \mathrm{O}$ series could be achieved by including more trees with only constant growth rates (e.g. for discs 1,3 and 4 in Figure 2). The sensitivity of $\delta^{18} \mathrm{O}$ to precipitation changes indicates the potential in $P$. elata tree rings for precipitation reconstructions before the historical record. Stable isotopes from tree-rings are available from Western (van der Sleen et al. 2015) and Eastern Africa (Gebrekirstos et al. 2009), but are very scarce (if not absent) in this area, which is characterized by a complex bimodal precipitation distribution (Figure 1d). Climate reconstructions from the Congo Basin, one of three major convective regions on the planet, are urgently needed to improve our understanding about synoptic climate systems delivering rainfall to the African rain forest, as also highlighted by disagreements in the existing model projections of future Congo rainfall (IPCC 2013).

\section{ACKNOWLEDGEMENTS}

This study was financed by the Swiss National Science Foundation to DC (grant no. PZOOP2_145077) and supported by the Belgian Federal Science Policy Office (grant no.BR/132/A1/AFRIFORD). We thank L. di Gesualdo for laboratory help and D.G. Gavin, W. Tinner, D. Verschuren and the AFRIFORD group for fruitful discussions. We are also grateful to one anonymous reviewer for the evaluation of the manuscript and improvements to the text. Data will be available upon request from the author.

\section{LITERATURE CITED}

AMPOFO, S. 1972. The problem of natural regeneration of Pericopsis elata (Harms) Van Meeuwen in Ghana. Journal of Agricultural Science 5:241-245.

ARAGUAS-ARAGUAS, L., FROEHLICH, K. \& ROZANSKI, K. 2000. Deuterium and oxygen-18 isotope composition of precipitation and atmospheric moisture. Hydrological Processes 14:1341-1355.

BARBOUR, M. M. 2007. Stable oxygen isotope composition of plant tissue: a review. Functional Plant Biology 34:83-94.

BOETTGER, T., HAUPT, M., KNOELLER, K., WEISE, S. M., WATERHOUSE, J. S., RINNE, K. T., LOADER, N. J., SONNINEN, E., JUNGNER, H., MASSON-DELMOTTE, V., STIEVENARD, M., GUILLEMIN, M.-T., PIERRE, M., PAZDUR, A., LEUENBERGER, M., FILOT, M., SAURER, M., REYNOLDS, C. E., HELLE, G. \& SCHLESER, G. H. 2007. Wood cellulose preparation methods and mass spectrometric analyses of delta $\mathrm{C}-13$, delta $\mathrm{O}-18$, and nonexchangeable delta $\mathrm{H}-2$ values in cellulose, sugar, and starch: an interlaboratory comparison. Analytical Chemistry 79:4603-4612.

BOURLAND, N., KOUADIO, Y. L., FETEKE, F., LEJEUNE, P. \& DOUCET, J.-L. 2012. Ecology and management of Pericopsis elata (Harms) Meeuwen (Fabaceae) populations. Biotechnologie, Agronomie, Société et Environnement 16:486-498.

BOURLAND, N., KOUADIO, Y. L., LEJEUNE, P., SONKE, B., PHILIPPART, J., DAINOU, K., FETEKE, F.\&DOUCET, J.-L. 2013. Ecology of Pericopsis elata (Fabaceae), an endangered timber species in Southeastern Cameroon. Biotropica 45:272.

BRIENEN, R., HELLE, G., PONS, T. L., GUYOT, J.-L. \& GLOOR, M. 2012. Oxygen isotopes in tree rings are a good proxy for Amazon precipitation and El Nino-Southern Oscillation variability. Proceedings of the National Academy of Sciences USA 109:1695716962.

BRIFFA, K. R. \& JONES, P. D. 1990. Basic chronology statistics and assessment. Pp. 137-152 in Cook, E. \& Kairiukstis, L. A. (eds.). Methods of dendrochronology: applications in the environmental sciences. Kluwer Academic Publishers, Dordrecht.

BRNCIC, T. M., WILLIS, K. J., HARRIS, D. J. \& WASHINGTON, R. 2007. Culture or climate? The relative influences of past processes on the composition of the lowland Congo rainforest. Philosophical Transactions of the Royal Society B-Biological Sciences 362:229-242. 
CAMBERLIN, P., MORON, V., OKOOLA, R., PHILIPPON, N. \& GITAU, W. 2009. Components of rainy seasons' variability in Equatorial East Africa: onset, cessation, rainfall frequency and intensity. Theoretical and Applied Climatology 98:237-249.

COLOMBAROLI, D., SSEMMANDA, I., GELORINI, V. \& VERSCHUREN, D. 2014. Contrasting long-term records of biomass burning in wet and dry savannas of equatorial East Africa. Global Change Biology 20:2903-2914.

COPLEN, T. B. 1995. Discontinuance of SMOW and PDB. Nature 375:285.

DANSGAARD, W. 1964. Stable isotopes in precipitation. Tellus 16:436468.

DE RIDDER, M., VAN DEN BULCKE, J., VAN ACKER, J. \& BEECKMAN, H. 2013a. Tree-ring analysis of an African long-lived pioneer species as a tool for sustainable forest management. Forest Ecology and Management 304:417-426.

DE RIDDER, M., TROUET, V., VAN DEN BULCKE, J., HUBAU, W., VAN ACKER, J. \& BEECKMAN, H. 2013b. A tree-ring based comparison of Terminalia superba climate-growth relationships in West and Central Africa. Trees-Structure and Function 27:1225-1238.

DE RIDDER, M., TOIRAMBE, B., VAN DEN BULCKE, J., BOURLAND, N., VAN ACKER, J. \& BEECKMAN, H. 2014. Dendrochronological potential in a semi-deciduous rainforest: the case of Pericopsis elata in Central Africa. Forests 5:3087-3106.

DETWILER, R. P.\& HALL, C. A. S. 1988. Tropical forests and the global carbon-cycle. Science 239:42-47.

DOUGLAS, A. E. 1941. Crossdating in dendrochronology. Journal of Forestry 39:825-831.

EPSTEIN, S., KRISHNAMURTHY, R. V., OESCHGER, H., EDDY, J. A. \& PECKER, J.-C. 1990. Environmental information in the isotopic record in trees. Philosophical Transactions of the Royal Society of London 330:427-439.

EVANS, M. N. \& SCHRAG, D. P. 2004. A stable isotope-based approach to tropical dendroclimatology. Geochimica et Cosmochimica Acta 68:3295-3305.

FARNSWORTH, A., WHITE, E., WILLIAMS, C. J. R., BLACK, E. \& KNIVETON, D. R. 2011. Understanding the large scale driving mechanisms of rainfall variability over Central Africa. African Climate and Climate Change: Physical, Social and Political Perspectives 43:101122.

FICHTLER, E., HELLE, G. \& WORBES, M. 2010. Stable-carbon isotope time series from tropical tree rings indicate a precipitation signal. Tree-Ring Research 66:35-49.

FRANCEY, R. J. \&FARQUHAR, G. D. 1982. An explanation of c-13/c-12 variations in tree rings. Nature 297:28-31.

FRANK, D., ESPER, J. \& COOK, E. R. 2007. Adjustment for proxy number and coherence in a large-scale temperature reconstruction. Geophysical Research Letters 34:1-5.

GAT, J. R. \& MATSUI, E. 1991. Atmospheric water-balance in the Amazon Basin - an isotopic evapotranspiration model. Journal of Geophysical Research - Atmospheres 96:13179-13188.

GEBREKIRSTOS, A., WORBES, M., TEKETAY, D., FETENE, M. \& MITLOEHNER, R. 2009. Stable carbon isotope ratios in tree rings of co-occurring species from semi-arid tropics in Africa: patterns and climatic signals. Global and Planetary Change 66:253-260.
GEBREKIRSTOS, A., BRAEUNING, A., SASS-KLASSEN, U. \& MBOW, C. 2014. Opportunities and applications of dendrochronology in Africa. Current Opinion in Environmental Sustainability 6:48-53.

HAGOS, S. M. \& COOK, K. H. 2008. Ocean warming and late-twentiethcentury Sahel drought and recovery. Journal of Climate 21:37973814.

HAWTHORNE, W. D. 1995. Ecological profiles of Ghanaian forest trees. Tropical Forestry Paper 29. Oxford Forestry Institute, Oxford.

HELLE, G. \& SCHLESER, G. H. 2004. Beyond $\mathrm{CO}_{2}$-fixation by Rubisco - an interpretation of $\mathrm{C}-13 / \mathrm{C}-12$ variations in tree rings from novel intra-seasonal studies on broad-leaf trees. Plant Cell and Environment 27:367-380.

IPCC. 2013. Climate change 2013: The Physical Science Basis Contribution of Working Group I. The fifth assessment report of the Intergovernmental Panel on Climate Change. Cambridge University Press, Cambridge.

KAHINDO MUHONGYA, J. M. 2011. Potentiel en produits forestiers autres que le bois d'oeuvre dans les formations forestières de la région de Kisangani. $\mathrm{PhD}$ thesis, University of Kisangani, $342 \mathrm{pp}$.

KRESS, A., SAURER, M., SIEGWOLF, R. T. W., FRANK, D. C., ESPER, J. \& BUGMANN, H. 2010. A 350 year drought reconstruction from Alpine tree ring stable isotopes. Global Biogeochemical Cycles 24:GB2011.

KYEREH, B., SWAINE, M. D. \& THOMPSON, J. 1999. Effect of light on the germination of forest trees in Ghana. Journal of Ecology 87:772-783.

LEAVITT, W. S. \& LONG, A. 1984. Sampling strategy for stable carbon isotope analysis of tree rings in pine. Nature 311:145-147.

LEVIN, N. E., ZIPSER, E. J. \& CERLING, T. E. 2009. Isotopic composition of waters from Ethiopia and Kenya: insights into moisture sources for eastern Africa. Journal of Geophysical Research - Atmospheres 114: D23306.

LOADER, N. J., YOUNG, G. H. F., MCCARROLL, D. \& WILSON, R. J. S. 2013. Quantifying uncertainty in isotope dendroclimatology. Holocene 23:1221-1226.

LOMBA-BOSOMBO, C. 2002. Systemes d'agregation et structures diametriques en fonction des temperaments de quelques essences dans les dispositifs permanents de Yoko et Biaro (Ubundu, Province Orientale, $R$. D. Congo). Unpubl. PhD thesis. Kisangani University, Kisangani.

MAYAUX, P., PEKEL, J.-F., DESDEE, B., DONNAY, F., LUPI, A., ACHARD, F., CLERICI, M., BODART, C., BRINK, A., NASI, R. \& BELWARD, A. 2013. State and evolution of the African rainforests between 1990 and 2010. Philosophical Transactions of the Royal Society B-Biological Sciences 368:20120300.

MBOW, C., CHHIN, S., SAMBOU, B. \& SKOLE, D. 2013. Potential of dendrochronology to assess annual rates of biomass productivity in savanna trees of West Africa. Dendrochronologia 31:41-51.

MCCARROLL, D. \& LOADER, N. J. 2004. Stable isotopes in tree rings. Quaternary Science Reviews 23:771-801.

MCCARROLL, D. \& PAWELLEK, F. 2001. Stable carbon isotope ratios of Pinus sylvestris from northern Finland and the potential for extracting a climate signal from long Fennoscandian chronologies. Holocene 11:517-526.

MCCARROLL, D., GAGEN, M., LOADER, N., ROBERTSON, I., ANCHUKAITIS, K., LOS, S., YOUNG, G., JALKANEN, R., KIRCHHEFER, A. \& WATERHOUSE, J. 2010. Correction of tree ring 
stable carbon isotope chronologies for changes in the carbon dioxide content of the atmosphere. Geochimica et Cosmochimica Acta 74:3040.

NICHOLSON, S. E. 2000. The nature of rainfall variability over Africa on time scales of decades to millennia. Global and Planetary Change 26:137-158.

OSLISLY, R., WHITE, L., BENTALEB, I., FAVIER, C., FONTUGNE, M., GILLET, J.-F. \& SEBAG, D. 2013. Climatic and cultural changes in the west Congo Basin forests over the past 5000 years. Philosophical Transactions of the Royal Society B-Biological Sciences 368:20120304.

OTTO, F. E. L., JONES, R. G., HALLADAY, K. \& ALLEN, M. R. 2013. Attribution of changes in precipitation patterns in African rainforests. Philosophical Transactions of the Royal Society B - Biological Sciences 368:20120299.

POUSSART, P. M., MYNENI, S. C. B. \& LANZIROTTI, A. 2006. Tropical dendrochemistry: a novel approach to estimate age and growth from ringless trees. Geophysical Research Letters 33:L17711.

REYNOLDS-HENNE, C. E., SIEGWOLF, R. T. W., TREYDTE, K. S., ESPER, J., HENNE, S. \& SAURER, M. 2007. Temporal stability of climate-isotope relationships in tree rings of oak and pine (Ticino, Switzerland). Global Biogeochemical Cycles 21:GB4009.

ROBERTSON, I., ROLFE, J., SWITSUR, V. R., CARTER, A. H. C., HALL, M. A., BARKER, A. C. \& WATERHOUSE, J. S. 1997. Signal strength and climate relationships in $\mathrm{C}-13 / \mathrm{C}-12$ ratios of tree ring cellulose from oak in southwest Finland. Geophysical Research Letters 24:14871490.

RODEN, J. S., LIN, G. G. \& EHLERINGER, J. R. 2000. A mechanistic model for interpretation of hydrogen and oxygen isotope ratios in tree-ring cellulose. Geochimica et Cosmochimica Acta 64:21-35.

ROZANSKI, K., ARAGUAS-ARAGUAS, L. \& GONFIANTINI, R. 1996. Isotope patterns of precipitation in the East African region. Pp. 7993 in Johnson, T. C. \& Odada, E. O. (eds.). The limnology, climatology and paleoclimatology of the East African Lakes. Gordon and Breach, Amsterdam.

ROZENDAAL, D. M. A. \& ZUIDEMA, P. A. 2011. Dendroecology in the tropics: a review. Trees - Structure and Function 25:3-16.

RUSSELL, J. M. \& JOHNSON, T. C. 2005. A high-resolution geochemical record from Lake Edward, Uganda Congo and the timing and causes of tropical African drought during the late Holocene. Quaternary Science Reviews 24:1375-1389.

SAMBA, G. \& NGANGA, D. 2012. Rainfall variability in CongoBrazzaville: 1932-2007. International Journal of Climatology 32:854873.

SAURER, M. \& SIEGWOLF, R. 2004. Pyrolysis techniques for oxygen isotope analysis of cellulose. Pp. 497-508 in De Groot, P. A. (ed.). Handbook of stable isotope analytical techniques. Elsevier, New York.

SAURER, M., SIEGENTHALER, U. \& SCHWEINGRUBER, F. 1995. The climate-carbon isotope relationship in tree rings and the significance of site conditions. Tellus Series B - Chemical and Physical Meteorology 47:320-330.

SAURER, M., BORELLA, S. \& LEUENBERGER, M. 1997. Delta O-18 of tree rings of beech (Fagus silvatica) as a record of delta $0-18$ of the growing season precipitation. Tellus Series B - Chemical and Physical Meteorology 49:80-92.

SCHLESER, G. H., HELLE, G., LUCKE, A. \& VOS, H. 1999. Isotope signals as climate proxies: the role of transfer functions in the study of terrestrial archives. Quaternary Science Reviews 18:927943.

VAN DER SLEEN, P., GROENENDIJK, P. \& ZUIDEMA, P. A. 2015. Treering delta O-18 in African mahogany (Entandrophragma utile) records regional precipitation and can be used for climate reconstructions. Global and Planetary Change 127:58-66.

VAN OLDENBORGH, G. J. \& BURGERS, G. 2005. Searching for decadal variations in ENSO precipitation teleconnections. Geophysical Research Letters 32:L15701.

VEENENDAAL, E. M., SWAINE, M. D., LECHA, R. T., WALSH, M. F., ABEBRESE, I. K. \& OWUSUAFRIYIE, K. 1996. Responses of West African forest tree seedlings to irradiance and soil fertility. Functional Ecology 10:501-511.

VERSCHUREN, D., DAMSTÉ, J. S. S., MOERNAUT, J., KRISTEN, I., BLAAUW, M., FAGOT, M., HAUG, G. H. \& CHALLACEA PROJECT MEMBERS. 2009. Half-precessional dynamics of monsoon rainfall near the East African Equator. Nature 462:637-641.

VIVIEN, J. \& FAURE, J. J. 2011. Arbres des forêts denses d'Afrique centrale. Editions Nguila-Kerou, Clohars-Carnoët. 945 pp.

WERNER, C. \& MAGUAS, C. 2010. Carbon isotope discrimination as a tracer of functional traits in a Mediterranean macchia plant community. Functional Plant Biology 37:467-477.

WEST, A. G., MIDGLEY, J. J. \& BOND, W. J. 2001. The evaluation of delta $\mathrm{C}-13$ isotopes of trees to determine past regeneration environments. Forest Ecology and Management 147:139-149.

WIGLEY, T. M. L., BRIFFA, K. R. \& JONES, P. D. 1984. On the average value of correlated time-series, with applications in dendroclimatology and hydrometeorology. Journal of Climate and Applied Meteorology 23:201-213.

WILliams, A. P., FUNK, C., MiCHAELSEN, J., RAUSCHER, S. A., ROBERTSON, I., WILS, T. H. G., KOPROWSKI, M., ESHETU, Z. \& LOADER, N. J. 2012. Recent summer precipitation trends in the Greater Horn of Africa and the emerging role of Indian Ocean sea surface temperature. Climate Dynamics 39:2307-2328.

WILS, T. H. G., ROBERTSON, I., ESHETU, Z., KOPROWSKI, M., SASSKLAASSEN, U. G. W., TOUCHAN, R. \& LOADER, N. J. 2010. Towards a reconstruction of Blue Nile baseflow from Ethiopian tree rings. Holocene 20:837-848.

WORBES, M., STASCHEL, R., ROLOFF, A. \& JUNK, W. J. 2003. Tree ring analysis reveals age structure, dynamics and wood production of a natural forest stand in Cameroon. Forest Ecology and Management 173:105-123.

ZELAZOWSKI, P., MALHI, Y., HUNTINGFORD, C., SITCH, S. \& FISHER, J. B. 2011. Changes in the potential distribution of humid tropical forests on a warmer planet. Philosophical Transactions of the Royal Society A - Mathematical Physical and Engineering Sciences 369:137160. 
(a)

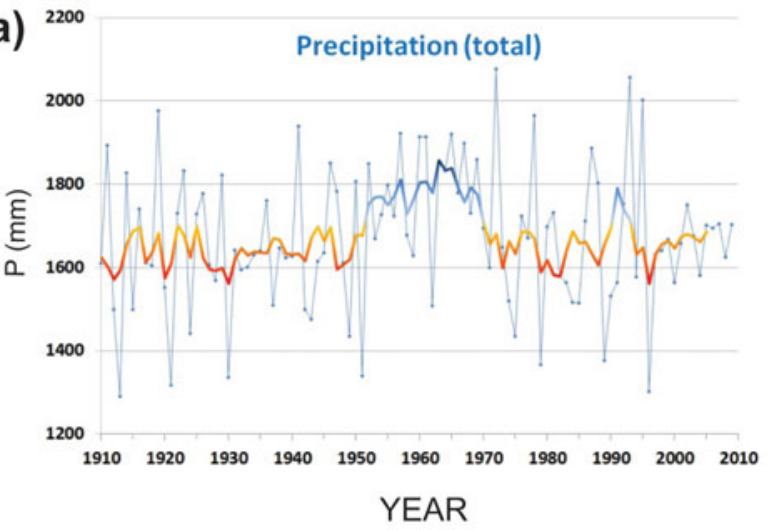

(b)

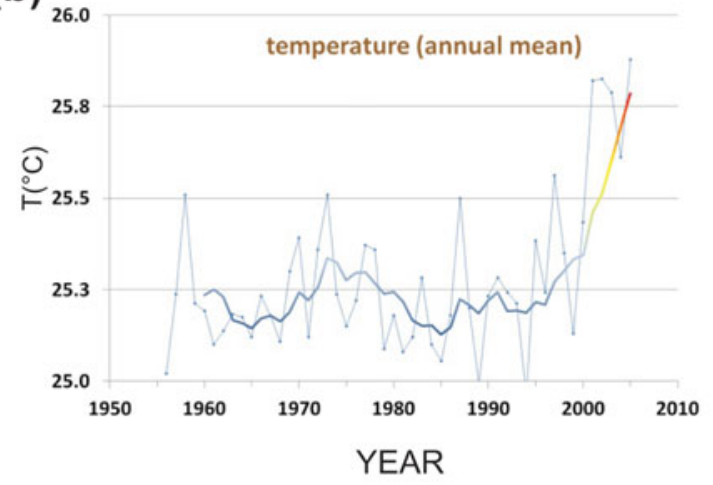

(c)

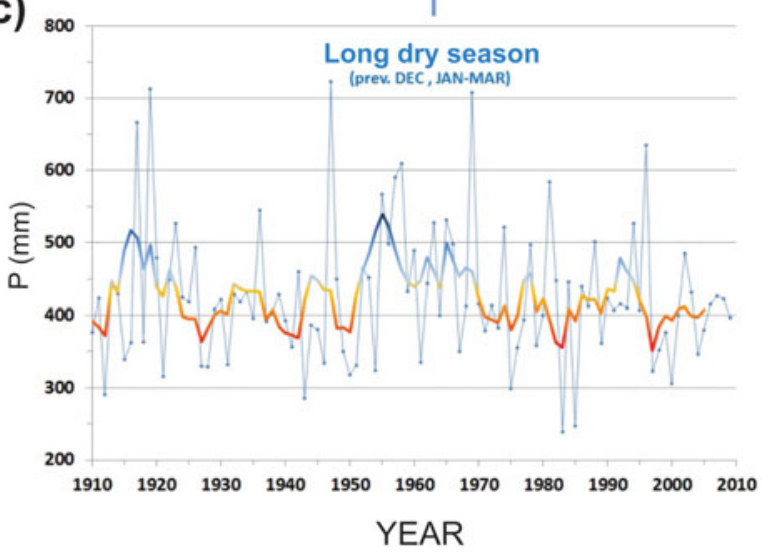

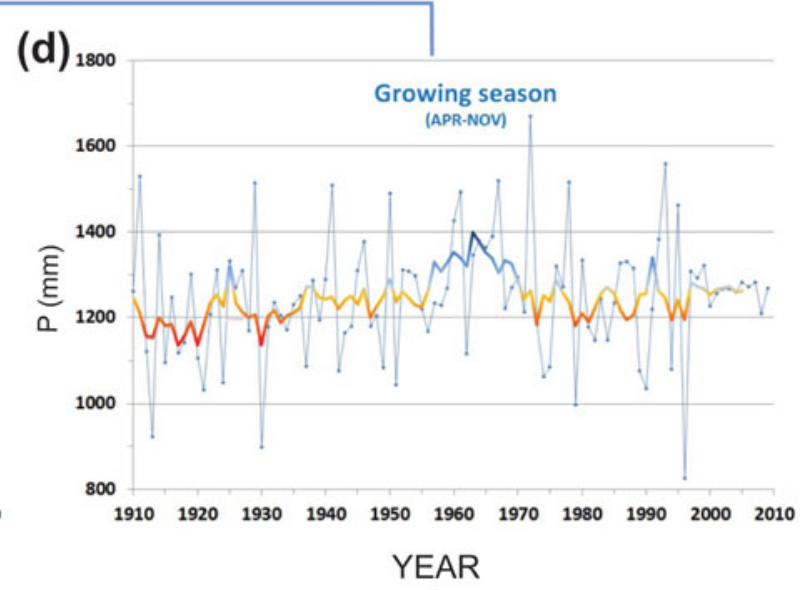

(e)
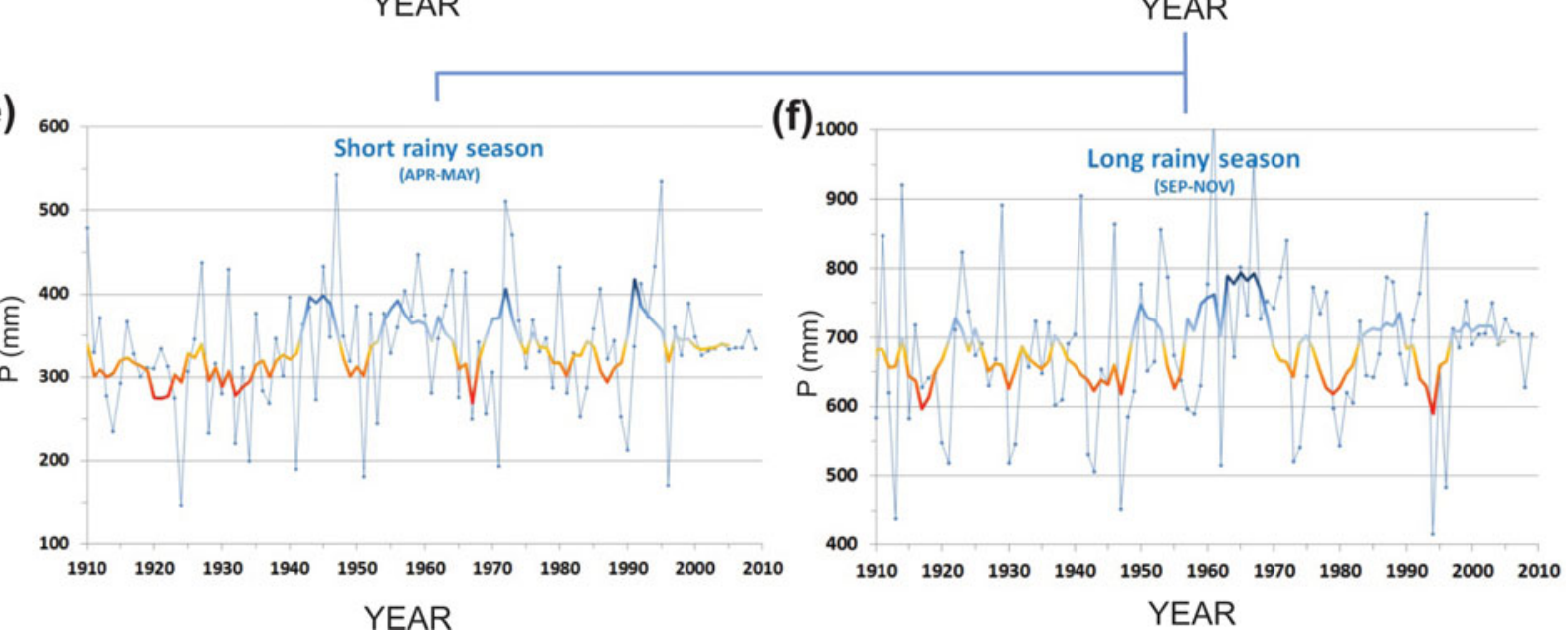

Appendix 1. Temperature and precipitation time series (a-b, Kisangani area), showing the relative contribution of seasonal precipitation (c-f) to total annual rainfall (a). The bimodal pattern in precipitation (long and short rainy seasons) is mostly associated with the latitudinal migration of the ITCZ (see main text). Precipitation data are from the NCAS British Atmospheric Data Centre, accessed with the KNMI climate explorer (van Oldenborgh \& Burgers 2005). Temperature data are from Kahindo Muhongya (2011). 
Appendix 2. Pearson's product-moment correlation values showing a weak linear relationship on the annual basis between stable isotopes $\left(\delta^{18} \mathrm{O}\right.$ and corrected $\delta^{13} \mathrm{C}$ ) measured on Pericopsis elata, and monthly precipitation in Eastern Congo (Kisangani area).

\begin{tabular}{|c|c|c|c|c|c|c|c|c|c|c|c|c|c|}
\hline Disc & $\begin{array}{l}\text { Stable } \\
\text { isotope }\end{array}$ & $\begin{array}{c}\text { January } \\
(\mathrm{mm})\end{array}$ & $\begin{array}{c}\text { February } \\
(\mathrm{mm})\end{array}$ & $\begin{array}{l}\text { March } \\
(\mathrm{mm})\end{array}$ & $\begin{array}{l}\text { April } \\
(\mathrm{mm})\end{array}$ & $\begin{array}{l}\text { May } \\
(\mathrm{mm})\end{array}$ & $\begin{array}{l}\text { June } \\
\text { (mm) }\end{array}$ & $\begin{array}{l}\text { July } \\
(\mathrm{mm})\end{array}$ & $\begin{array}{c}\text { August } \\
(\mathrm{mm})\end{array}$ & $\begin{array}{l}\text { September } \\
(\mathrm{mm})\end{array}$ & $\begin{array}{l}\text { October } \\
(\mathrm{mm})\end{array}$ & $\begin{array}{l}\text { November } \\
\quad(\mathrm{mm})\end{array}$ & $\begin{array}{l}\text { December } \\
(\mathrm{mm})\end{array}$ \\
\hline \multirow[t]{2}{*}{1} & Carbon & -0.03 & 0.08 & 0.00 & 0.11 & -0.14 & 0.09 & -0.20 & 0.07 & -0.06 & 0.24 & 0.31 & 0.29 \\
\hline & Oxygen & -0.04 & -0.09 & 0.10 & -0.02 & -0.05 & 0.15 & -0.23 & 0.05 & -0.04 & 0.02 & -0.02 & 0.12 \\
\hline \multirow[t]{2}{*}{2} & Carbon & 0.21 & -0.15 & -0.02 & 0.17 & 0.18 & -0.10 & 0.16 & 0.05 & 0.15 & -0.09 & 0.06 & 0.14 \\
\hline & Oxygen & -0.14 & -0.01 & -0.10 & -0.03 & 0.00 & 0.08 & -0.15 & 0.01 & -0.12 & -0.10 & 0.16 & 0.12 \\
\hline \multirow[t]{2}{*}{3} & Carbon & -0.09 & 0.04 & 0.03 & 0.02 & -0.18 & 0.19 & -0.20 & -0.27 & -0.02 & 0.11 & 0.24 & 0.10 \\
\hline & Oxygen & -0.17 & -0.08 & 0.05 & -0.07 & -0.07 & -0.08 & 0.01 & -0.09 & -0.01 & -0.02 & 0.02 & -0.03 \\
\hline \multirow[t]{2}{*}{4} & Carbon & -0.21 & 0.11 & -0.22 & -0.08 & -0.07 & 0.04 & -0.33 & -0.30 & 0.11 & 0.00 & 0.20 & 0.03 \\
\hline & Oxygen & -0.19 & -0.03 & 0.13 & -0.07 & -0.10 & 0.15 & 0.03 & -0.07 & 0.04 & 0.19 & 0.19 & -0.01 \\
\hline
\end{tabular}

Appendix 3. Pearson's product-moment correlation considering the seasonal distribution of precipitation in Eastern Congo (Kisangani area), with the growing season for Pericopsis elata between April and November.

\begin{tabular}{lcccccc}
\hline Disc & Stable & $\begin{array}{c}\text { Long dry } \\
\text { season } \\
\text { (December- } \\
\text { isotope }\end{array}$ & $\begin{array}{c}\text { Short dry } \\
\text { season } \\
\text { (June-July) }\end{array}$ & $\begin{array}{c}\text { Short rainy } \\
\text { season } \\
\text { (April- } \\
\text { May) }\end{array}$ & $\begin{array}{c}\text { Long rainy } \\
\text { season } \\
\text { (August- } \\
\text { November) }\end{array}$ & $\begin{array}{c}\text { Growing } \\
\text { season } \\
\text { (April- } \\
\text { November) }\end{array}$ \\
\hline $\mathbf{1}$ & Carbon & -0.10 & -0.03 & -0.08 & 0.12 & 0.04 \\
$\mathbf{2}$ & Oxygen & 0.08 & -0.10 & -0.22 & 0.18 & -0.02 \\
& Carbon & 0.04 & 0.10 & -0.20 & 0.17 & 0.09 \\
$\mathbf{3}$ & Oxygen & -0.01 & 0.12 & -0.10 & 0.10 & 0.08 \\
$\mathbf{4}$ & Carbon & 0.05 & 0.08 & -0.21 & 0.24 & 0.13 \\
& Oxygen & 0.02 & 0.07 & -0.17 & 0.29 & 0.19 \\
& Carbon & 0.17 & 0.08 & -0.10 & 0.11 & 0.08 \\
& Oxygen & 0.19 & -0.04 & 0.03 & 0.13 & 0.11 \\
\hline
\end{tabular}

